\title{
sciendo
}

CIVIL AND ENVIRONMENTAL ENGINEERING REPORTS

E-ISSN 2450-8594

CEER 2019; 29 (1): 053-065

DOI: $10.2478 /$ ceer-2019-0005

Original Research Article

\section{DEVELOPMENT OF THE EXPERIMENTAL STAND WITH CENTRALLY LOCATED SPECIMEN FOR THE INVESTIGATION OF HEAT AND MOISTURE PHENOMENA IN POROUS BUILDING MATERIALS}

\author{
Łukasz CIEŚLIKIEWICZ ${ }^{1}$, Michał WASIK, Michał KUBIŚ, Piotr ŁAPKA, \\ Marcin BUGAJ, Karol PIETRAK, Tomasz S. WIŚNIEWSKI, \\ Piotr FURMAŃSKI, Mirosław SEREDYŃSKI \\ Warsaw University of Technology, Warsaw, Poland
}

\begin{abstract}
The paper presents development of an experimental stand with centrally located specimen for the investigation of heating and drying processes in porous building materials. Additionally, the paper contains preliminary results of measurements which test and verify the assumed operation conditions of the stand. In order to control parameters of air which was used to heat and dry the specimen, the stand was operating in a closed loop and was equipped with several elements, i.e., the cooler (humidity condenser), fan with variable rotation speed, humidifier and heater. Moreover, the stand consisted of two square and parallel ducts with air streams which had identical parameters. This allowed for two measurements at the same time.
\end{abstract}

Keywords: drying of porous materials; drying measurements; building materials; experimental stand

\footnotetext{
1 Corresponding author: Institute of Heat Engineering, Faculty of Power and Aeronautical Engineering, Warsaw University of Technology, Nowowiejska st. 21/25, 00-665 Warsaw, Poland, e-mail: lukasz.cieslikiewicz@itc.pw.edu.pl, tel. +48222345253
} 


\section{INTRODUCTION}

Building structures are sensitive to the moisture content in building materials. Many sources of water in porous building materials might be found, e.g., condensation of water vapour from moist air, rising of groundwater level and precipitation are typical examples. Moisture deteriorates properties of building thermal insulations, changes mechanical properties of building materials, induces biological corrosion and salts decay $[12,13,19]$. Moreover, it influences indoor microclimate conditions as well as affects the comfort of occupants and their health, which refers to the sick building syndrome [17]. Water in building materials might be accumulated for a long time, especially in historical buildings $[7,9]$.

Drying process is characterised by complicated mathematical description based on partial differential equations, which in practical cases can not be solved analytically. Therefore, researchers are developing numerical models which involve the Computational Fluid Dynamics (CFD) to simulate combined heat, mass and fluid flow $[3,4,8,15,16,20]$. These models take into consideration each phase (vapour, dry air, solid phase and liquid moisture) separately or collectively by balancing moisture amount in the material $[3,8,20]$. Numerical models allow for computing moisture transfer assuming the equilibrium state between water vapour and liquid water $[16,20]$ or considering the local non-equilibrium state $[3,4,8]$. The wide range of models with different assumptions and different but equivalent systems of equations have to be validated and compared for the same conditions applying experimental data obtained from the specially-designed validation experiments. The influence of modelling assumptions on calculated results and their matching with experimental measurements should be analysed. The drying process in porous media is present not only in the case of drying of building materials but also in, e.g., the food processing, paper production, crops drying and garments. The wide range of different types of dried media results in the significant potential for complex research. To the authors' knowledge, validations of numerical models concerning various types of materials (e.g., brick, cloth, food, etc.) applying the same experimental stand were not reported in the literature.

Different drying techniques were proposed, e.g., the convective $[2,6,11,18,21]$, vacuum [18] and microwave drying [5,6]. The convective drying process is widely used particularly in the food processing for which the influence of the pretreatment of samples on the process kinetic was examined in a wind tunnel under air velocity and temperature of $2 \mathrm{~m} / \mathrm{s}$ and $60^{\circ} \mathrm{C}$, respectively [2]. Junqueira et al. [11] noticed that, the problem in modelling of convective drying, especially in fruits, is related mainly to availability of material properties, which might depend on the pre-treatment. These parameters should be determined experimentally. 
Moreover, the convective drying might be combined with the microwave or vacuum drying to obtain the higher drying ratio. It was found that the combined convective and vacuum drying attains good kinetic at relatively low temperature, e.g., at $55^{\circ} \mathrm{C}$ [21]. The convective drying with microwave assistance was exanimated in $[6,18]$ and also showed good result in increasing drying kinetics. However, the main disadvantage of the microwave drying process is significant increase of the medium temperature, which might be harmful for sensitive samples, e.g., for food. The automatic temperature control during the microwave drying was proposed in [5]. Moreover, the ultrasound and convective drying was also exanimated [18]. Although, better convection parameters were obtained, the energy efficiency of the ultrasound was low [18].

In order to analyse the drying process different experimental stands were built which accounted for different drying mechanisms. In the case of drying of existing buildings, most important is the convective drying in which moisture and heat transfer between flowing air and sample depends on local climate conditions, e.g., the air velocity, temperature and relative humidity [12]. For this reason, the range of these air flow parameters influences the experimental stand development. For example, the experiment may be conducted in free convection conditions or with low velocity forced convection in a climatic chamber $[1,10]$. For high speed forced convection, special wind tunnels are built. These tunnels are of either open-flow $[6,20]$ or closed-loop [12] type. Experiments described in the literature were conducted with air flow velocities up to $5 \mathrm{~m} / \mathrm{s}[12,20]$ and relative humidity as high as $35 \%$ and $44 \%$.

The convective drying process of whole brick or section of the wall placed in the wind tunnel was not investigated experimentally till now. Instead, experiments with small specimens (e.g., samples of dimensions of $3 \times 3 \times 3 \mathrm{~cm}$ ) or with convective heat and moisture transfer at one surface of the sample were conducted $[12,20]$.

\section{EXPERIMENTAL STAND}

\subsection{Main assumptions}

The developed stand met several requirements. Majority of them concerned the following parameters of the working fluid (air):

- velocity,

- temperature,

- relative humidity.

These parameters have to be measured and controlled in the following range: 0.1 $10 \mathrm{~m} / \mathrm{s}, 15-60^{\circ} \mathrm{C}$ and $10-90 \%$, respectively. Additionally, in order to obtain data 
for the validation of numerical models developed parallelly [14] the following parameters in dried materials were measured:

- temperature distribution on the surface and within the specimen,

- moisture content distribution within the specimen,

- global moisture content.

\subsection{Main concept}

During development of the experimental stand two main concepts were initially considered:

- open-flow (Fig. 2),

- closed-loop flow (Fig. 1).

In both cases, the system consisted of the following elements (numbers listed below refers to respective numbers in Fig. 1 and Fig. 2):

1. cooler/condenser,

2. heater,

3. humidifier,

4. stabilizer,

5. integrated velocity, temperature and humidity transmitter,

6. sample holder and force meter,

7. sample,

8. integrated temperature and humidity transmitter,

9. fan,

10. throttle.

a)

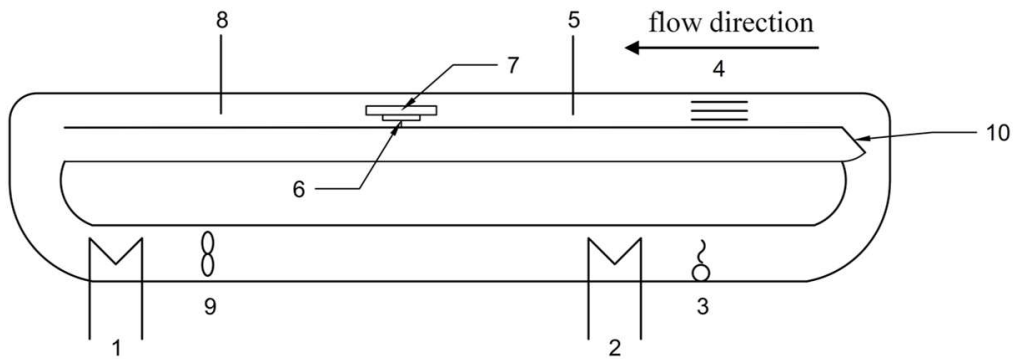

b)

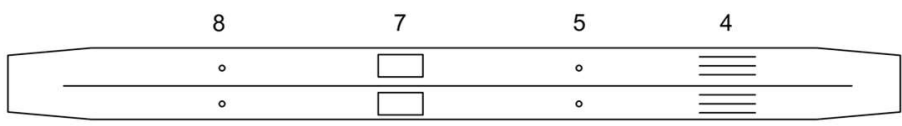

Fig. 1. Simplified schematic of the closed-loop flow experimental stand: a) side view and b) top view 


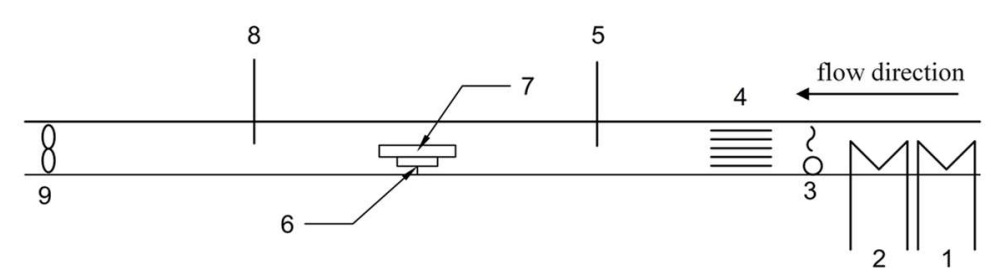

Fig. 2. Simplified schematic of the open-flow experimental stand

Fig. 1 and Fig. 2 graphically present both concepts (closed-loop and open-flow test stands) and their elements denoted by numbers from 1 to 10 . The closed-loop stand includes 3 channels which enable two simultaneously measurements in the same conditions. After initial verification, the closed-loop flow stand was chosen for the further development. Main arguments for selection of this variant were following: lower power required by the heater, cooler and humidifier, ability to achieve operational parameters in few cycles, less dependence on the environmental conditions, less impact on the surroundings and the ability to investigate two specimens in identical conditions at the same time.

\subsection{Construction}

The experimental stand was built as modular construction divided into three parts. Each part contains of the upper and lower duct. The lower duct is round and the upper one is square and split into three internal channels (see Fig. 3). Outermost parts of the stand include connections between the upper and lower ducts which consist of two $90^{\circ}$ bends and round-to-square connectors. The upper duct is split into three internal channels (see Fig. 3), two identical on the top and one bigger at the bottom. In top internal channels measurement areas are located. The bottom channel is used in the first stage of the experiment for stabilization of operating conditions of the stand. All air conditioning equipment is in the lower duct (see elements no. 1-3 and 9 in Fig. 1). In the first part, the cooler/condenser (1) and fan (9) are placed. The cooler/condenser is made of a copper pipe twisted into a spiral and connected to a refrigerated circulation bath with glycol. This solution allows for both air cooling in case of measurements at low temperatures and removal of excessive moisture which reduces the relative humidity to assumed level. The localization of the cooler shortly before the fan protects it from overheating. The fan, with rotation speed controlled by a frequency inverter, allows for smooth changes of the air velocity from $3.5 \mathrm{~m} / \mathrm{s}$ up to $10 \mathrm{~m} / \mathrm{s}$. In order to reduce the flow velocity below $3.5 \mathrm{~m} / \mathrm{s}$ (i.e., in the range from 0.1 to $3.5 \mathrm{~m} / \mathrm{s}$ ), the throttle (10) situated in the third part or additional resistance in top channels of the upper duct may be used. In the third part the electrical heater (2) of $3 \mathrm{~kW}$ of power and the 
humidifier (3) are located. The humidifier is made of a pipe with gap at lower pressure side, connected with a tank with mist. Mist is produced by an ultrasonic, piezoelectric mist generator. To stabilize and homogenize the flow field after the round-to-square connector and throttle, stabilizers (4) in top channels of the upper duct were applied. Stabilizers were made of an array of several small square channels of cross-section dimensions equal to $25 \times 30 \mathrm{~mm}$ and length of $300 \mathrm{~mm}$ placed inside both measurement channels as shown Fig. 3. In the middle part of the stand top channels of the upper duct contain places for specimens (7) and force meters (6), i.e., measurement areas, with sample holders (6) which allow for adjustment of the level and position of the sample.

a)

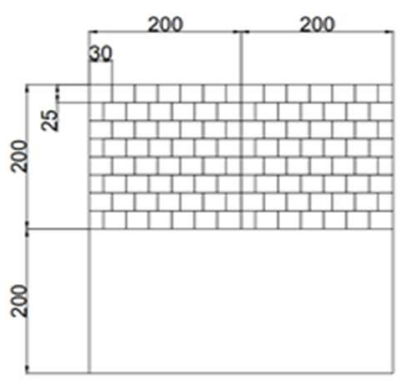

b)

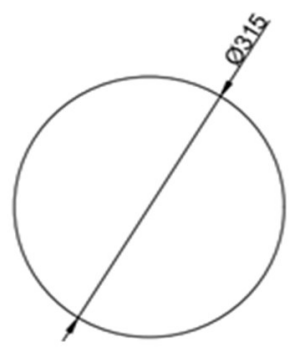

Fig. 3. Cross-sections of ducts with dimensions: a) the square upper duct divided into three internal channels and $b$ ) the round lower duct

\subsection{Acquisition and control}

In order to measure the air velocity, the thermo-anemometer was applied in the integrated with temperature and relative humidity measurement probe connected to the analog transmitter and placed before the sample (see elements no. 5 in Fig. 1). Additional integrated temperature and humidity transmitter (8) was also used after the sample. Temperature distribution on the top surface of the sample was registered by the IR thermography. Moreover, to measure temperature inside the sample K-type sheath thermocouples of $0.5 \mathrm{~mm}$ diameter were applied. The measurement of the global moisture content was made gravimetrically with two force meters (6) per the sample. The moisture content distribution was measured with a system of resistance meters. All signals were converted in a multifunction data acquisition (DAQ) instrument connected with a computer with dedicated inhouse software developed in the LabView environment. Digital outputs of the DAQ equipment were used to control solid-state relays and regulate parameters inside the experimental stand. 


\section{TEST MEASUREMENT}

\subsection{Stability measurement}

In order to verify the stability of controlled parameters several measurements were conducted. The standard deviation and difference from the mean value were principal indicators applied for the stand evaluation. Table 1 contains experimentally-obtained values of stability indicators, while Fig. 4 presents variations of controlled parameters. Results shown in Table 1 and Fig. 4 proved that the obtained stability of controlled parameters (i.e., velocity, temperature and relative humidity of air) is high.

Table 1. Stability indicators for air parameters

\begin{tabular}{|c|c|c|c|}
\hline Indicator & Velocity $[\mathbf{m} / \mathbf{s}]$ & Temperature $\left[{ }^{\circ} \mathbf{C}\right]$ & $\begin{array}{c}\text { Relative humidity } \\
{[\%]}\end{array}$ \\
\hline Standard deviation & 0.056 & 0.13 & 0.064 \\
\hline $\begin{array}{c}\text { Maximum spread } \\
\text { from mean }\end{array}$ & 0.20 & 0.26 & 0.13 \\
\hline
\end{tabular}

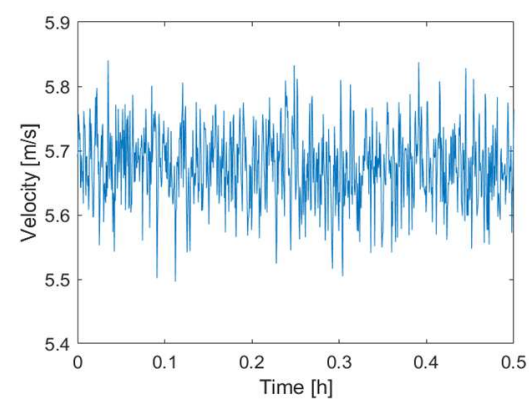

b)

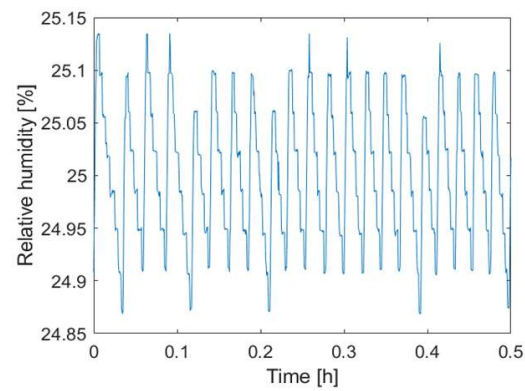

c)

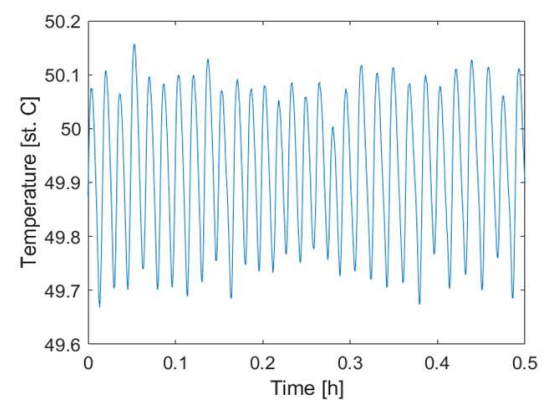

Fig. 4. Variations of: a) velocity, b) temperature and c) relative humidity of air flowing in the stand 


\subsection{Drying tests}

In order to verify the functional correctness of the stand, several measurements have been carried out. Fig. 5 and 6 present results for drying of the whole ceramic brick with the initial moisture content of $13.5 \%$. Air conditions during measurements were following:

- air velocity of $9.9 \mathrm{~m} / \mathrm{s}$,

- air temperature of $50^{\circ} \mathrm{C}$,

- air relative humidity of $25 \%$.

Before measurements the specimen was fully-submerged in water for 24 hours to obtain the high moisture content. After this period the specimen was wrapped in plastic foil and conditioned in $60^{\circ} \mathrm{C}$ for another $24 \mathrm{~h}$ to obtain homogeneous moisture distribution.

a)

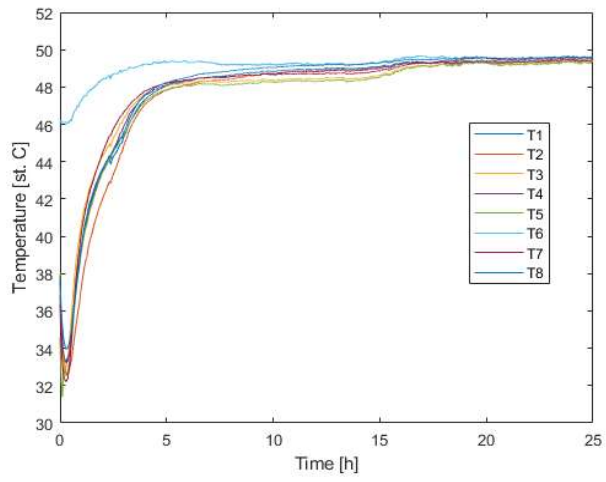

b)

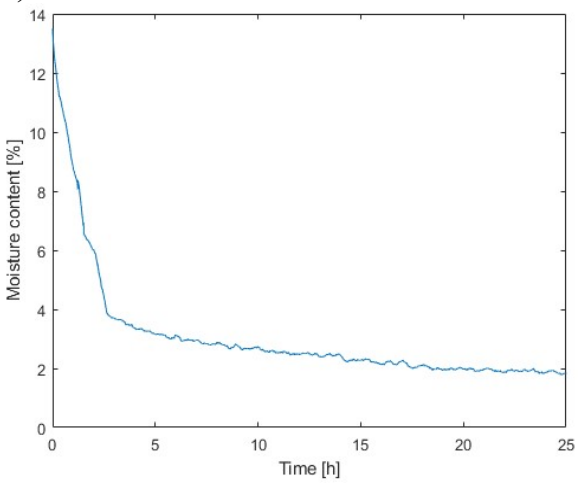

Fig. 5. Variation of: a) temperature in different locations inside the sample and b) total moisture content in the specimen dried by air velocity of $9.9 \mathrm{~m} / \mathrm{s}$, temperature of $50^{\circ} \mathrm{C}$ and relative humidity of $25 \%$

The locations of thermocouples (see Fig. 5) in the sample were following:

- $\quad \mathrm{T} 1$ - middle of the sample, $5 \mathrm{~mm}$ deep from the top surface,

- T2, T3 $-6 \mathrm{~cm}$ from the front and rear edges in the half width of the sample, $5 \mathrm{~mm}$ deep from the top surface,

- T4, T5 $-3 \mathrm{~cm}$ from the side edges in the half length of the sample, $5 \mathrm{~mm}$ deep from the top surface,

- T6 - middle of the rear surface, $5 \mathrm{~mm}$ deep,

- $\quad$ T7 - middle of the side surface, $5 \mathrm{~mm}$ deep,

- $\quad \mathrm{T} 8$ - middle of the front surface, $5 \mathrm{~mm}$ deep. 
a)

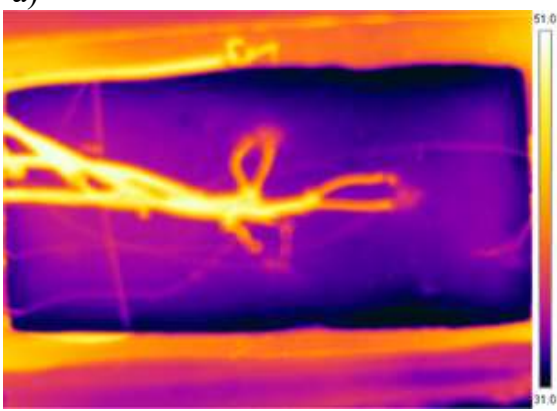

c)

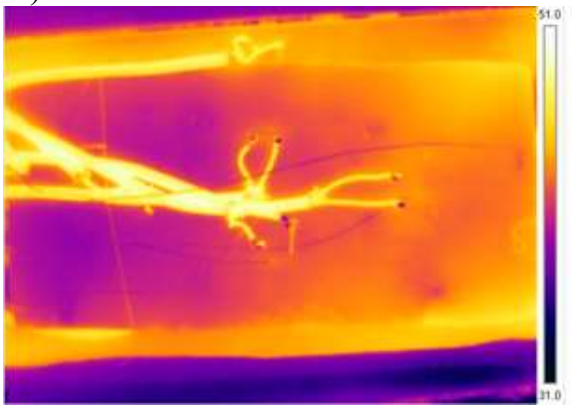

e)

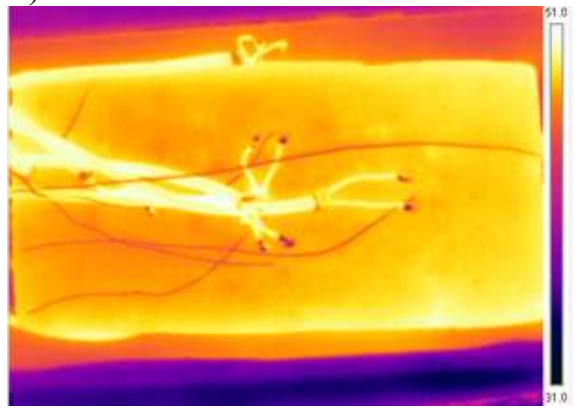

b)

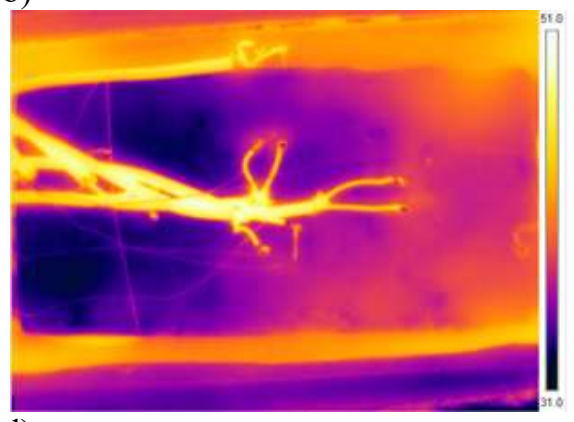

d)

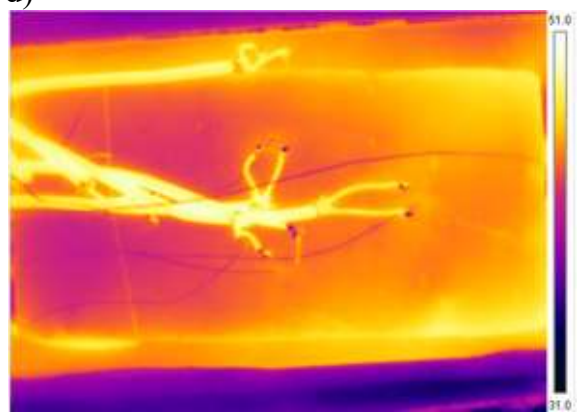

f)

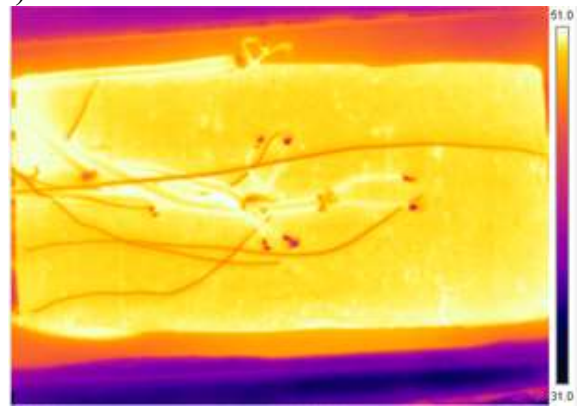

Fig. 6. Temperature distribution at the top surface of the specimen after: a) $1 \mathrm{~min}$, b) $35 \mathrm{~min}$, c) $85 \mathrm{~min}$, d) $2.1 \mathrm{~h}$, e) $3.6 \mathrm{~h}$ and f) $17.5 \mathrm{~h}$ for drying air at velocity of $9.9 \mathrm{~m} / \mathrm{s}$, temperature of $50^{\circ} \mathrm{C}$ and relative humidity of $25 \%$ (the minimum scale temperature is $31^{\circ} \mathrm{C}$ and the maximum one is $51^{\circ} \mathrm{C}$ )

The first stage of drying resulted in the rapid decrease of temperature to saturation conditions - see Fig. 5. This stage was characterised by fast water evaporation and reduction of the moisture content in the sample. Later on in the second stage, increase of the sample temperature towards flowing air temperature was observed. Temperature distributions on the top surface of the specimen at different stages of the drying are also presented in Fig. 6. Brighter lines on the specimen are resistant 
meters, while darker ones are thermocouples guided on the top surface. It was found that the location of the drying front is strongly connected with temperature distribution. The saturation temperature and the front proceed together with the flow direction, i.e., from the right to left side. After evaporation of liquid water, the sample temperature started to increase.

\section{CONCLUSION}

The presented experimental stand with centrally located specimen meets the requirements and assumptions related to controlling of operating conditions in the wide ranges. These ranges are wider than for stands presented in the literature. Moreover, stands which allowed for variation of the relative humidity were not reported, e.g., in $[12,19]$ all measurements were carried out with one fixed value of the relative humidity. Velocity range in the present stand is two times wider than for stands used in the literature [12,19]. Good stability of controlled conditions shown in verification measurements indicates that the test stand is ready for future experiments. In the next step measurements with different operating conditions will be carried out in order to examine duration and energy consumption of the drying process for various building materials. Additionally, this stand will be applied for validation of mathematical and numerical models of heat and moisture transfer in porous building materials which are developed in parallel [14].

\section{ACKNOWLEDGEMENTS}

This work was supported by the National Centre for Research and Development (Poland) under grant no. POIR.04.01.02-00-0099/16 Development of innovative technology of drying and moisture sealing of masonry walls, DryWall.

\section{REFERENCES}

1. Bianchi Janetti, M, Colombo, LPM, Ochs, F and Feist, W 2017. Determination of the water retention curve from drying experiments using infrared thermography: A preliminary study. International Journal of Thermal Sciences 114, 271-280.

2. Castro, AM, Mayorga, EY and Moreno, FL 2018. Mathematical modelling of convective drying of fruits: A review. Journal of Food Engineering 223, 152 167.

3. Cheng, X and Fan, J 2004. Simulation of heat and moisture transfer with phase change and mobile condensates in fibrous insulation. International Journal of Thermal Sciences 43, 665-676. 
4. Costa, VAF, Mendonça, ML and Figueiredo, AR 2008. Modeling and simulation of wetted porous thermal barriers operating under high temperature or high heat flux. International Journal of Heat and Mass Transfer 51, 33423354.

5. Cuccurullo, G, Giordano, L, Metallo, A and Cinquanta, L 2018. Drying rate control in microwave assisted processing of sliced apples. Biosystems Engineering 170, 24-30.

6. Das, I and Arora, A 2018. Alternate microwave and convective hot air application for rapid mushroom drying. Journal of Food Engineering 223, 208-219.

7. Falchi, L, Slanzi, D, Balliana, E, Driussi, G and Zendri, E 2018. Rising damp in historical buildings: A Venetian perspective. Building and Environment 131, 117-127.

8. Fan, J and Wen, X 2002. Modeling heat and moisture transfer through fibrous insulation with phase change and mobile condensates. International Journal of Heat and Mass Transfer 45, 4045-4055.

9. Gueli, AM, Garro, V, Liuzzo, M, Margani, G, Pasquale, S, Politi, G and Stella, $\mathrm{G}$ 2018. Effects of moisture on historical buildings TL ages. Measurement 118, 289-297.

10. Janssen, H, Scheffler, GA and Plagge, R 2016. Experimental study of dynamic effects in moisture transfer in building materials. International Journal of Heat and Mass Transfer 98, 141-149.

11. Junqueira, JRdJ, Corrêa, JLG, de Oliveira, HM, Ivo Soares Avelar, R and Salles Pio, LA 2017. Convective drying of cape gooseberry fruits: Effect of pretreatments on kinetics and quality parameters. LWT - Food Science and Technology 82, 404-410.

12. Karagiannis, N, Karoglou, M, Bakolas, A, Krokida, M and Moropoulou, A 2017. Drying kinetics of building materials capillary moisture. Construction and Building Materials 137, 441-449.

13. Lourenço, PB, Luso, E and Almeida, MG 2006. Defects and moisture problems in buildings from historical city centres: A case study in Portugal. Building and Environment 41, 223-234.

14. Łapka, P, Wasik, M, Furmański, P, Seredyński, M, Cieślikiewicz, Ł, Pietrak K, Kubiś, M, Wiśniewski, TS and Jaworski, M 2018. Preliminary mathematical and numerical transient models of convective heating and drying of a brick. MATEC Web of Conferences 240, 01022.

15. Pel, L, Landman, KA and Kaasschieter, EF 2002. Analytic solution for the non-linear drying problem. International Journal of Heat and Mass Transfer 45, 3173-3180.

16. Salagnac, P, Glouannec, P and Lecharpentier, D 2004. Numerical modeling of heat and mass transfer in porous medium during combined hot air, infrared 
and microwaves drying. International Journal of Heat and Mass Transfer 47, 4479-4489.

17. Shoemaker, RC and House DE 2006. Sick building syndrome (SBS) and exposure to water-damaged buildings: Time series study, clinical trial and mechanisms. Neurotoxicology and Teratology 28, 573-588.

18. Szadzińska, J, Kowalski, SJ and Stasiak, M 2016. Microwave and ultrasound enhancement of convective drying of strawberries: Experimental and modeling efficiency. International Journal of Heat and Mass Transfer 103, $1065-1074$.

19. Trochonowicz, M 2010. Wilgoć w obiektach budowlanych. Problematyka badań wilgotnościowych. Budownictwo i Architektura 7, 131-144.

20. Van Belleghem, M, Steeman, M, Janssen, H, Janssens, A and De Paepe, M 2014. Validation of a coupled heat, vapour and liquid moisture transport model for porous materials implemented in CFD. Building and Environment 81, 340-353.

21. Zecchi, B, Clavijo, L, Martínez Garreiro, J and Gerla, P 2011. Modeling and minimizing process time of combined convective and vacuum drying of mushrooms and parsley. Journal of Food Engineering 104, 49-55.

\section{ROZWÓJ STANOWISKA DOŚWIADCZALNEGO Z CENTRALNIE \\ UMIESZCZONĄ PRÓBKĄ DO BADAŃ PROCESU GRZANIA I SUSZENIA POROWATYCH MATERIAŁÓW BUDOWLANYCH}

\section{Streszczenie}

$\mathrm{W}$ artykule przedstawiono prace nad stanowiskiem doświadczalnym $\mathrm{z}$ centralnie umieszczoną próbką do badań procesu grzania i suszenia porowatych materiałów budowlanych. Dodatkowo $\mathrm{w}$ artykule zawarto wstępne wyniki pomiarów, które weryfikują zakładane warunki pracy stanowiska. W celu kontroli parametrów powietrza wykorzystywanego do podgrzewania i suszenia próbki, stanowisko pracowało w pętli zamkniętej i było wyposażone w kilka elementów, tj. chłodnicę (jednocześnie osuszacz powietrza), wentylator o zmiennej prędkości obrotowej, nawilżacz i nagrzewnicę. Aby uzyskać dwa strumienie powietrza o identycznych parametrach, pozwalające na wykonanie dwóch pomiarów w tym samym czasie i weryfikację powtarzalności proponowanej metody badawczej, układ składał się $\mathrm{z}$ dwóch kwadratowych i równoległych kanałów pomiarowych. Próbka została umieszczona w środku każdego kanału, co pozwoliło na wielowymiarowy transport ciepła i wilgoci wewnątrz próbki. $\mathrm{W}$ trakcie pomiarów zmierzono wilgotność w różnych położeniach i całkowitą wilgotność próbki, stosując odpowiednio system mierników rezystancji i siłomierza. Zmienność temperatury próbki mierzono kilkoma termoparami typu $\mathrm{K}$ i termografią w podczerwieni. 
DEVELOPMENT OF THE EXPERIMENTAL STAND WITH CENTRALLY LOCATED

Pomiary eksperymentalne przeprowadzono dla następujących zakresów prędkości powietrza, temperatury i wilgotności względnej: $0,1-10 \mathrm{~m} / \mathrm{s}, 15^{\circ} \mathrm{C}-60^{\circ} \mathrm{C}$ i $10-90 \%$. Podczas pomiarów rejestrowano i analizowano czasowe zmiany temperatury i wilgotności w kilku punktach próbki oraz zmiany całkowitej ilości wilgoci w próbce.

Słowa kluczowe: suszenie materiałów, pomiary procesu suszenia, materiały budowlane, stanowisko doświadczalne

Editor received the manuscript: 15.01.2019 